\title{
The Effect of Strategic Leadership, Organization Innovativeness, Information Technology Capability on Effective Strategy Implementation: A Study of Tertiary Institutions in Nigeria
}

\author{
Ahmad Aliyu Palladan ${ }^{1}$, Kadzrina Binti Abdulkadir ${ }^{2}$, Yen Wan Chong ${ }^{3}$ \\ ${ }^{I}$ College of Business, Universiti Utara Malaysia \\ ${ }^{2}$ PhD College of Business, Universiti Utara Malaysia \\ ${ }^{3} \mathrm{PhD}$ College of Business, Universiti Utara Malaysia
}

\begin{abstract}
This is a literature-based paper. The paper has conceptualized a simple model comprising of four variables, namely strategic leadership, organizational innovative, information technology capability and effective strategy implementation. Because previous studies have only concentrated in profit oriented organization, especially in Europe, America and Asia. This paper is an attempts to move outward the frontier of knowledge concerning the relationship strategic leadership behaviours (SLP), organizational innovativeness $(O I V)$, information technology capability (ITC) on effective strategy implementation (ESE) by looking at it from different context namely, Nigeria. A survey study of cross-sectional nature will be conducted thirteen (13) in tertiary institutions located in Kaduna State. The institutions located in the state are major element in Nigeria's educational sector, the sector that is currently experiencing serious and major reforms targeted toward enhancing its service delivery and quality. Contextual performance in the form of strategic leadership behaviours, organizational innovation attitude (innovativeness) and IT capability promotes the effectiveness of the institutions. This is because of their positive relationship with organization effectiveness in its strategy implementation. This paper proposes that having strategic leaders in place couple with innovation attitude and IT capability of the institutions will increase the efficiency of the overall institutions due proper implementation of good and reputable strategies. In todys world were knowledge economy strives, tertiary institutions have great role to play in socio economic and political growth, especially in developing country like Nigeria.
\end{abstract}

Keywords: Strategic Leadership, Organizational Innovation, IT Capability, Effective Strategy Implementation

\section{Introduction}

One of the most central areas of concern among contemporary organizational theorists and practitioners is organizational effectiveness. A good mechanism for achieving it is effective strategy implementation (Sharbat \& Fuqaha, 2014; Ali \& Hadi, 2012). Effective Strategy execution is a process by which strategies are put into concrete action through improvement of programs, budgets, and actions. The process is often referred to as operational planning and usually comprise the allocation of day-to-day decisions in resource allocations (Wheelen \& Hunger, 2008). More so, Thompson et al. (2008) concur that effective strategy execution is an operations-oriented and make-things happen activity that promote core organizational activities in a strategy supportive manner. The plan strategies, argued Daft (2009), gives an organization a competitive edge only if it is effectively implemented through the decisions and actions of strategic leaders.

Facts from the extant literature reveals that competitive advantages rooted in organizational internal competencies can be more safer in creating benefits for institutions, in contrast to its external opportunities (Arasa \& K'obonyo, 2012). One of the organizational internal competitive superiorities is leadership style (Safarzadeh et al. 2015). Strategic leadership have been widely accepted as popular leadership styles visible that plays an effective and significant role in gaining competitive advantages (Yazdani, 2009). Leadership, and particularly strategic leadership, is widely believed to be one of the key drivers of efficient strategy execution (Hrebiniak 2005; Kaplan \& Norton 2004; Thompson \& Strickland 2003; Freedman \& Tregoe 2003; Bossidy \& Charan 2002; Lynch 2006; Josste \& Fourie, 2009; Noble 1999; Ulrich, Zenger \& Smallwood 1999; Collins 2001; Pearce \& Robinson 2007). Nonetheless, lack of leadership, and particularly strategic leadership by the top management of organisations has been pencilled as one of the major inhibitors to effective strategy execution (Alexander 1985; Business Day 1999; Beer \& Eisenstat 2000; Kaplan \& Norton 2004 and Hrebiniak 2005).

Organizational innovativeness is widely considered as a critical source of competitive advantage in the contemporary changing environment (Dess \& Picken, 2000; Tushman \& O'Reilly, 1996). According to management scholars, innovation capability (innovativeness) is the most essential determinant of organizational effectiveness (Mone, McKinley \& Barker, 1998) Innovativeness could be defined as a mental process that guide to the invention of a new phenomenon; the phenomenon may be spiritual product (the new service or new 
techniques) or new material . Innovativeness is known as a crucial factor for organizations to create value and maintain competitive advantage in today's highly multifaceted, and dynamic environment. Organizations that accept innovativeness and engage in innovation, responding to contemporary changes and build up new capabilities that will help them to attain higher performance will be more thriving (Moghli et al., 2012).

Strategic leadership was hypothesized to have a positive impact on organizational innovativeness (Safarzadeh et al. 2015). Also, strategic leaders have been repetitively recognized for their decisive role in recognizing opportunities and taking positive decisions that will have impact on innovation process (Safarzadeh et al. 2015). More so, strategic leadership and organizational innovativeness are considered to be fundamentals for achieving and maintaining strategic competitiveness in the 21st century (Elenkov et al., 2005).

According to Bharadwaj (2000), IT capability is organizational ability to mobilize and deploy IT based resources combined with other resources and capabilities. Thus, IT capability as a moderating variable is introduced in this study to see whether the relationship between strategic leadership, organizational innovativeness and effective strategy implementation will be strengthening or weakened with the inclusion of the moderator. Past researches such as Ringim, Osman and Hasnan, (2013); Shao, Feng, Choudnie and Liu (2010); Said, Taylor and Othman, (2009) and Youngmei, Hongjian and Junhua (2008) used IT capabilities as a moderating variable in different context. More so, Babalola (2007) assert that the major reform and development that is taking place in HEIs is due to the significant of IT which has positively influenced teaching and researches in the institutions. Furthermore, one of the major reforms recommend by World Bank (2000) to tertiary institutions is IT. Hence, there is need to comprehend the impact of IT capability attributes to the relationship between strategic leadership, organizational innovativeness and effective strategy implementation in Nigerian public tertiary institutions. Consequently, in the context of Nigeria, there is no existing study to the best of knowledge of this researcher that integrate and combine strategic leadership and organizational innovativeness while considering IT capabilities in assessing the effectiveness of strategy implementation in Nigerian tertiary institutions.

\section{Strategic Leadership}

Leadership in general and Strategic leadership in particular, is widely regarded by numerous scholars as one of the key elements for effective strategy implementation (Lynch 2006; Noble 1999; Ulrich, Zenger \& Smallwood 1999; Collins 2001; Bossidy \& Charan 2002; Thompson \& Strickland 2003; Freedman \& Tregoe 2003; Kaplan \& Norton 2004; Pearce \& Robinson 2007; Hrebiniak 2005). Lack of leadership, specifically strategic leadership in an organisation, has been pencilled as one of the major obstacles to effective strategy execution (Alexander 1985; Beer \& Eisenstat 2000; Kaplan \& Norton 2004; Hrebiniak 2005).

Strategic leadership as defined by Hitt Ireland \& Hoskisson, (2007 p375) is "the leader's ability to anticipate, envision, and maintain flexibility and to empower others to create strategic change as necessary". Strategic leadership is versatile. It involves managing through subordinates, and helps organisations to cope with changes that seem to be increasing dramatically in today's globalised business environment (Huey 1994). Strategic leadership demands for the ability to integrate both the inside and outside business environment of the organisation, and engage in multifaceted information processing. Several identifiable actions and features qualify strategic leadership as postulated by Hitt et al. (2007). These qualities contribute positively to effective strategy execution.

i. Identifying the strategic direction to follow

ii. Setting and establishing standard organisational controls

iii. Managing organisational resources effectively

iv. Maintaining an effective organizational culture

v. Emphasising ethical practice

Strategic leaders play a significant role in all of the above-mentioned strategic actions. Consequently, each of these strategic leadership actions positively contributes to effective strategy implementation. Hence, Glantz (2002) stress the need for managers to find an appropriate leadership style. This is very true especially when it comes to implementation of important and daunting managerial techniques like strategy that is more about change. Bringing about change, especially in higher education institutions, is not an easy task. Because the institutions are characterised by vagueness in their mission and their tendency toward anarchy (Vroom, 1984).

\section{Organizational Innovativeness}

According to Hurley and Hult (1998), organizational innovativeness is the thought of openness to new ideas as a characteristic of a firm's culture. Thus, innovativeness is a gauge of an organization's orientation toward innovation. There are requisites to organizational innovativeness as argued Hurley and Hult (1998). These organizational characteristics include organizational culture, such as learning, participative decision 
making, collaboration and support, and power sharing etc. The capacity to innovate, is a term firstly used by Burns and Stalker (1961), as the organizational ability to adopt or implement new ideas, processes, or products successfully. Tertiary institutions that have a greater ability to innovate "are able to develop a competitive advantage and achieve higher levels of effectiveness" Hurley and Hult (1998). In this study, organizational innovativeness is used as unidimensional construct (Hurley and Hult, 1998). This represents the behavioural aspect of innovation of organization (Wang and Ahmed, 2004). The behavioural innovativeness reflects the "sustained behavioural change" of the organisation leading to innovations, i.e. behavioural commitment (Avlonitis et al., 1994).

Innovation is rapidly becoming a key strategic implementation driver for organizations as we advance further into this century (Stanleigh, 2015). Innovativeness at the tertiary institutions level may involve the implementation of a new technical ideas or a new administrative ideas (Damanpour \& Evan, 1984). The adoption of a new idea in an organization, regardless of the time of its adoption in the related organizational population, is expected to result in an organizational change that might affect the organizational strategy implementation performance and other aspects (Damanpour \& Evan, 1984).

\section{The Concept of It Capability}

Ross, Beath \& Goodhue in 1996, promulgated the concept of IT capability. They defined IT capability as the organization's ability to bring together, integrate and deploy IT based resources. Bharadwaj (2000) widened the explanation of the accepted views of organizational IT capabilities to an organization's IT function. IT capability, argued Bharadwaj (2000) is the ability of a organization to mobilize and deploy IT based resources in combination with other resources and capabilities. IT-based resources consist of technical and managerial IT skills, as well as intangible IT-enabled resources such as knowledge, assets, customer orientation and synergy i.e. the sharing of resources and capabilities across organizational departments. Consequently, capabilities refer to the ability of organization to combine resources to promote superior performance and achieve competitive advantage (Amit \& Schoemaker, 1993).

Sosik, Jung, Berson, Dionne \& Jaussi (2005) said that studies reveals that $40 \%$ of all information technology (IT) development projects are cancelled before completion. The primary factor responsible for their failure is a lack of strategic leadership. This shows how close is the relationship between strategic leadership and information technology when it comes to strategy implementation. Dimitris, Sakes, \& Vlachos (2013) argued that strategic leaders must take decisions regarding organizational strategy implementation on a various issues and the information needed for those decisions are stored or available as the computer database. Thus, information technology could facilitate the decision making and makes strategy implementation more quicker and easier. Incomplete information and properties and languages of the database can produce communication problems and endanger the effectiveness of information processing and in turn affect effective strategy implementation by strategic leaders (Dimitris, Sakes, \& Vlachos, 2013).

\section{Effective Strategy Implementation}

Regardless of type and level of strategy in an organization, in the end superiors are always "faced with the straightforward task of simply getting things done" (Hrebiniak 2005 p.57). Effective strategy implementation is then concerned with putting strategy into practice and can be described as the implementation of tactics so that the organization moves in the needed strategic direction (Giles 1991).

Effective implementation of strategies are more difficult than formulating strategies (Hrebiniak, 2008). Gurowitz (2007) opined that only less than $10 \%$ of well-formulated strategies are effectively executed. More so, the same results of just $10 \%$ of strategies being effectively executed is also reported by Judson (1991) and Speculand (2006). Correspondingly, Farsight, (2007) study discover that $80 \%$ of organizations have the right strategies, but unfortunately only $14 \%$ implement them effectively. Presently, empirical findings on effective strategy execution are therefore far from encouraging (Cater \& Pucko, 2010). Noble (1999), also argued that deep and cohesive body of literatures in the area of effective strategy implementation are noticeably absence; and of course this must have consequences for organizational practice. Effective strategic implementation can help higher education institutions to revamp their performance and leap ahead of their competitors. Execution of organisational strategy is a persistent theme in both strategic management and organizational skills. Constant academic study and empirical evidence confirm that successful strategy execution piloted by strategic leaders and innovation ability of an organization has a momentous impact on the organizational performance (Hrebiniak \& Joyce, 1984); and it is fundamental for accomplishment of operational efficiency and subsequently, attainment of organizational effectiveness. In line with this, Sproull and Hofmeister (1986) aver that successful and effective strategy implementation is crucial to the smooth functioning of an organization. Schilit (1987) and Noble (1999) corroborate that it is an indispensable essential element for the success of both public and private organizations. 
The study is based on the framework depicted below, that is developed through extensive literature review and information gathered from several sources. Both the two independent variables (strategic leadership and organizational innovativeness) and the dependent variable (effective strategy implementation), are all unidimensional variables. While the moderator, IT capability is multi dimensional variable.

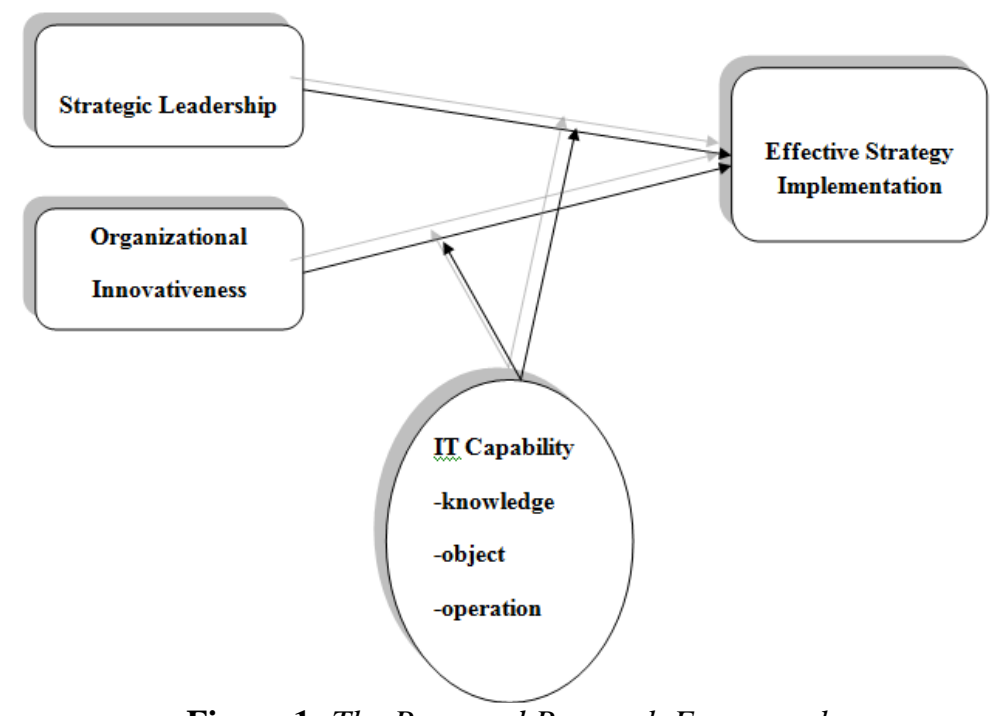

Figure 1: The Proposed Research Framework

After extensive literature review, the following prepositions were made.

Preposition 1: There is positive relationship between strategic leadership and effective strategy implementation in Nigerian public tertiary institutions

Preposition 2: There is positive relationship between organizational innovativeness and effective strategy implementation in Nigerian public tertiary institutions

Preposition 3: IT capabilities moderate the relationship between strategic leadership and effective strategy implementation in public tertiary institutions in Nigeria

Preposition 4: IT capabilities moderate the relationship between organizational innovativeness and effective strategy implementation in public tertiary institutions.

\section{Population and Sample}

\section{Methodology}

The population of the study will consist of the thirteen (13) public tertiary institutions located in Kaduna state, Nigeria. The state is being referred to as the 'centre of learning' in Nigeria due to the high number and unique tertiary institutions located in the state. The state is third largest state in Nigeria behind Kano and Lagos states (NPC, 2006). The organizations will serve as unit of analysis for the study; while Deans from these institutions will serve as the respondents to the survey to be administered, due to the important role they play in implementation of any meaningful strategy in their institutions. Hence, many respondents will be considered from each institution. Strategy gurus opined that using several respondents from each institution in strategy research tend to limit potential measurement error (Bowman \& Amborsini, 1997; Niyyar, 1992; Hambrick, 1981; Snow \& Hrebiniak, 1980). Moreover, in the contrary, taking single respondent in an institution may lead to unrealistic outcome (Bowman \& Amborsini, 1997). Hence, this study intends to contact 118 deans that come from the institutions. In other words, the unit of analysis for the study are the organizations.

\section{Measurement}

To measure the various variables in this, a structured survey will be used. The questionnaire will comprise of two major segments. Section one deals with the variables under investigation, while section two solicit information about the respondents demographic profile. The four variable employed, strategic leadership behaviour (Wendy Lear, 2012); organizational innovativeness (Hurley \& Hult, 1998); IT capability (Tippins and Sohi, 2003) and effective strategy implementation (Mintzberg, 2004) will be measured using six Likert scale (1 $=$ Strongly Disagree to $6=$ Strongly Agree). It will measure the degree to which the respondents agree or disagree with each of the statements. The questions for strategic leadership behaviours will be adapted from the previous works by Baum et al. (1998), Bass \& Avolio (1992) and House (1998). For organizational innovativeness the indicators are from Rainey (1999) and Hurley \& Hult (1998). IT capability are adapted from 
Tippins and Sohi (2003) and finally for effective strategy implementation, the measure were adapted from (Mintzberg, 2004) .

\section{Techniques for Data Analysis}

Four main data techniques analyses will be employed to analysis the data to be collected from the field survey. Firstly, the descriptive analysis will be used to summarise the respondents' demographic profile. PLS SEM technique that is referred to as the second generation structural equation modelling by (Wold, 1982) will be used for the main data analysis. The somewhat new technique works well with structural equation models that containing latent variables and a series of cause-and-effect relationships (Gustafsson \& Johnson, 2004). To confirm the hypotheses (propositions) in the study, a correlation analysis technique will be used, this will certainly assist in checking inter-relationship between variables and their direction of their relationship and after that, the regression analysis will be applied to test the hypotheses. This will go a long way in helping to establish the nature of their relationship.

\section{Underpinning Theory}

Resource Base View will be use to underpinned the study. Popularly known as RBV, the theory is a very popular in management science. RVB implies that organizations can leapfrog over their rivals through developing resources that are distinctive and diversely distributed (Barney, 1991). The theory meant to explains the correlation and relationship between organizational resources and gaining competitive advantage for superior success (Fahy, 2000; Barney, 1991).

\section{Conclusion}

The paper examines the effect strategic leadership, organizational innovativeness on effective strategy implementation, while employing IT capability serving as moderator. As noted earlier, the significant positive relationship between strategic leadership behaviours and effective strategy implementation has been well documented. Though, there are very few researches that relate organizational innovation ability (innovativeness) with strategy implementation, yet the few researches available shows positive correlation between organizations innovation ability and it efficiency. Thus, with the introduction of moderating variable, the relationship ought to be improved. To enhance organizational effectiveness through strategy implementation, tertiary institutions need to have visionary leaders that will enhance the attitude of innovation in the organizations, as well as coupling with proper utilization of available IT infrastructures in the institutions. Conclusively, the paper contributes to body of knowledge by providing a conceptual framework that combines two unique variables and also employing the role of IT capability attributes on the relation of effective strategy implementation.

\section{References}

[1] Alexander, L.D. 1985. Successfully implementing strategic decisions, Long Range Planning. 18(3): 91-97.

[2] Ali, M., \& Hadi, A. 2012. Surveying and identifying the factors affecting successful implementation of business strategies in companies of Fars province industrial towns (case study: companies of food industries). International Journal of Business and Social Science, 3(1), 265-272.

[3] Amit, R., \& Shoemaker, H. J. P. 1993.Strategic assets and organisational rent. Strategic Management Journal, $14,33-46$.

[4] Arasa, R., \& K'Obonyo, P. 2012. The relationship between strategic planning and firm performance. International Journal of Humanities and Social Science, 2(22), 201-213.

[5] Avlonitis, G.J., Kouremenos, A. and Tzokas, N. 1994. Assessing the innovativeness of organizations and its antecedents Project Innovstrat. European Journal of Marketing, 28 (11), 5-28

[6] Babalola, J. B. 2007. Access, equity and quality in higher education. NAEAP.

[7] Cater, T., \& Pucko, D. 2010. Factors of effective strategy implementation: Empirical evidence from Slovenian business practice. Journal for East European Management Studies, 15(3), 207-236.

[8] Badawi, G. (2009). Public Library Services and the Information Needs of Women in Northern Nigeria. Samaru Journal of Information Studies, 9(2)

[9] Barney, J. (1991). Firm resources and sustained competitive advantage. Journal of management, 17(1), 99-120.

[10] Bass, B. M., \& Avolio, B. J. (1992). Organizational description questionnaire: Sampler set. Mind Garden, Incorporated.

[11] .Beer, M. \& Eisenstat, R.A. (2000). 'The six silent killers of strategy implementation', Sloan Management Review. 29.

[12] Bharadwaj, A. (2000). A resource-based perspective on information technology capability and firm performance: An empirical investigation. MIS Quarterly, 24, 169-196.

[13] Bossidy, L. \& Charan, R. (2002). Execution: The Discipline of Getting Things Done. London: Random House.

[14] Business Day. 1999. 'Reasons why companies fail to execute strategy', Business Day, 30 September: 37.

[15] Collins, J. (2001). Good to Great. London: Random House.

[16] Damanpour, F., \& Evan, W. M. (1984). Organizational innovation and performance: the problem of" organizational lag". Administrative science quarterly, 392-409.

[17] Dimitrios, N. K., Sakas, D. P., \& Vlachos, D. S. (2013). Analysis of strategic leadership models in information technology. Procedia-Social and Behavioral Sciences, 73, 268-275.

[18] Daft, R. (2009). Management (9th Edition).USA: South Western, Cengage Learning.

[19] Dess, G. G. and Picken, J. C. (2000). 'Changing roles: leadership in the 21 st century'.Organizational Dynamics,28, 18-34.

[20] Elenkov, D; Judge, W; Wright, P.(2005). Strategic leadership and executive innovation influence: An international multi-cluster Comparative study. Strategic management Journal, 26, 665-682 
[21] Fahy, J. (2000). The resource-based view of the firm: Some stumbling block on the road to understanding sustainable competitive advantage. Journal of European Industrial Training, 24(2 3/4), 94-104

[22] Farsight Leadership Organisation (2015): Strategy implementation and realisation, www.businessballs.com/businessstrategyimplementation.htm, 24.10.2015.

[23] Freedman, M. \& Tregoe, B.B. 2003. The Art and Discipline of Strategic Leadership. New York: McGraw-Hill.

[24] Giles, W.D. (1991): Making strategy work, in: Long Range Planning, 24, 5, 75-91

[25] Gustafsson, A., \& Johnson, M. D. (2004). Determining attribute importance in a service satisfaction model. Journal of Service Research, 7, 2, 124-41.

[26] Gurowitz, E.M. (2015): The challenge of strategy implementation, www.gurowitz.com/ articles/strategy.pdf, 26.10.2015.

[27] Hambrick, D.C. (1981). Strategic Awareness within the Top Management Team. Strategic Management Journal, 2, 263-279

[28] Hitt, M.A., Ireland, R.D. \& Hoskisson, R.E. (2007). Strategic Management: Competitiveness and Globalization, (ed). Ohio: Thomson/South Western

[29] Hrebiniak, L.G. (2005): A strategic look at strategy execution, in: Optimize, 4, 3, 57-59.

[30] Hrebiniak, L.G. (2008): Making strategy work: Overcoming the obstacles to effective execution, in: Ivey Business Journal Online, $72,2,1$.

[31] Huey, J. (1994). The new post-heroic leadership. Fortune, 21, 42-50.

[32] Hurley, R. F., \& Hult, G. T. M. (1998). Innovation, market orientation, and organizational learning: an integration and empirical examination. The Journal of Marketing, 62(3), 42-54.

[33] Hrebiniak L, \& Joyce W (1984). Implementing Strategy. Macmillian. New York. NY.

[34] House Robert, J. (1998). Appendix: Measures and assessments for the charismatic leadership approach: Scales, latent constructs, loadings, Cronbach alphas, interclass correlations. Fred, Dansereau, Yammarino Francis J, editors. Leadership: The multiple level approaches contemporary and alternative. London, UK: JAI.

[35] Judson, A.S. (1991): Invest in a high-yield strategic plan, in: Journal of Business Strategy, 12, Jooste, C., \& Fourie, B. (2009). The role of strategic leadership in effective strategy implementation: Perceptions of South African strategic leaders. Southern African Business Review, 13(3).

[36] Kaplan, R.S. \& Norton, D.P. 2004. Strategy Maps: Turning Intangible Assets into Tangible Results. oston, MA: Harvard Business School Press.ynch, R. L., \& Smith, J. R. (2006). Corporate strategy. Harlow, England: FT/Prentice Hall. 4, 34-39

[37] Moghli.A; Al Abdullah, G; Al muala, A. (2012). Impact of innovation on realizing competitive advantage in banking sector in Jordan. American Academic \& Scholarly Research Journal, 4 (5), 1-9.

[38] Mintzberg, H. (2004). Managers, not MBAs: A hard look at the soft practice of managing and management development. BerrettKoehler Publishers.

[39] Mone, M. A., McKinley, W. and Barker, V. L. (1998). Organizational decline and innovation: a contingency framework. Academy of Management Review, 23, 115-32.

[40] .Noble, C.H. (1999): The eclectic roots of strategy implementation research, in: Journal of Business Research, 45, 2, 119-134

[41] Niyyar, P. (1992). On the Management of Corporate Diversification Strategy: Evidence from Large US Service Firms. Strategic Management Journal, 13, 219-235

[42] Noble, C.H. (1999). 'The eclectic roots of strategy implementation research', Journal of Business Research, 45: 119-134

[43] NPC (2006). National Population Commission 2006 Census result retrieved from: http://www.population.gov.ng/index.php/state-population 15 November, 2014

[44] Pearce, J.A. \& Robinson, R.B. 2007. Formulation, Implementation and Control of Competitive Strategy, (ed). Boston, MA: McGraw-Hill Irwin

[45] Ringim, K. J., Osman, N. H., Hasnan, N., \& Razalli, M. R. (2013). Exploring the implementation of business process reengineering in banks. Asian Social Science, 9(11),243

[46] Ross, J., Beath, C., \& Goodhue, D. (1996). Develop long-term competitiveness through information technology assets. Sloan Management Review, 38(1), 31-42

[47] Safarzadeh, T., Dahghan, E., Pazireh, M., \& Pouraskari, F. (2015). Checking the relationship between strategic leadership, competitive advantage and organizational performance with mediating role of innovation. International Journal of Business and Behavioural Science. 5(1), 11-18

[48] .Said, J., Hui, W. S., Taylor, D., \& Othman, R. (2009). Customer-Focused Strategies and Information Technology Capabilities: For Service Quality of Malaysian Local Authorities. International Review of Business Research Papers, 5(3), 241-256.

[49] Schilit, W.K. (1987) An Examination of the Influence of Middle-Level Managers in Formulating and Implementing Strategic Decisions, Journal of Management Studies, 24(3), 271-293.

[50] Shao, Z., Feng, Y., Hu, J. H., \& Liu, H. J. (2008). A conceptual Model for studying the influence of charismatic Leadership on ERP implementation life style. Paper presented at the $42^{\text {nd }}$ Hawaii International Conference on System Science, Hawaii USA

[51] Sharabati, A. A. A., \& Fuqaha, S. J. (2014). The Impact of Strategic Management on the Jordanian Pharmaceutical Manufacturing Organizations' Business Performance.International Review of Business and Management Research, 3(2), 668- 687

[52] Snow, C.C. \& Hrebiniak, L.G. (1980). Strategy, Distinctive and Organizational Performance. Administrative Science Quarterly, $25,317-335$

[53] Sosik, J. J., Jung, D. I., Berson, Y., Dionne, S. D., \& Jaussi, K. S. (2005). Making All the Right Connections:: The Strategic Leadership of Top Executives in High-Tech Organizations. Organizational Dynamics, 34(1), 47-61.

[54] Speculand, R. (2006): The great big strategy challenge, in: Strategic Direction, 22, 3, 3-5.

[55] Stalker, G. M. \& Burns, T.E. (1961). The management of innovation. University of Illinois at Urbana-Champaign's Academy for Entrepreneurial Leadership Historical Research Reference in Entrepreneurship.

[56] Sproull, L.S. \& Hofmeister (1986). Thinking about implementation. Journal of Management, 12(1), 43-60.

[57] Stanleigh, M. (2015). 7 Key Trends in Innovation. Retrieved from: www.bia.ca/articles/7KeyTrendsinInnovation.htm. August, 2015 .

[58] Thompson, A., Strickland, A.J., and Gamble, J. (2008). Crafting and Executing Strategy: Texts and Readings (16th Edition). New York: Business Publications.

[59] Tushman, M. \& Nadler, D. (1986). Organizing for innovation. California Management Review. 28(3), 74-92.

[60] Ulrich, D., Zenger, J. \& Smallwood, N. (1999). Results-based Leadership. Boston, MA:Harvard Business School Press.

[61] Wang, C. L., \& Ahmed, P. K. (2004). The development and validation of the organisational innovativeness construct using confirmatory factor analysis. European Journal of Innovation Management, 7(4), 303-313.

[62] Wendy, L; (2012). The relationship between strategic leadership and strategic alignment in high performance companies in South Africa, PHD thesis, Dept. Business Administration, University of South Africa 
[63] Wheelen, T.L. and Hunger, L.D. (2008). Strategic Management and Business Policy (11 ${ }^{\text {th }}$ Edition). England: Prentice Hall.

[64] Wold, H. (1985). Systems analysis by Partial Least Squares. In P.Nijkamp, H. Leitner \& N. Wrigley (Eds.), Measuring the immeasurable: 221-252. Martinus Nijhoff: Dordrecht.World Bank (2000) Retrieved from: http://www.worldbank.org/en/country/nigeria 19, March 2015.

[65] Yazdani, M. (2009). Offering process model to application of knowledge management, based on organizational learning. Journal of IT management, 1, 6-86.

[66] Yongmei, L., Hongjian, L., \& Junhua, H. (2008). Information technology capability as moderator between information technology investment and firm's performance. Tsinghua Science and Technology, 13. 